\title{
Strategi Pemasaran Sekolah Dalam Peningkatan Minat Peserta Didik Berdasarkan Delta Model
}

\author{
Ririn Tius Eka Margareta \\ Magister Manajemen Pendidikan Universitas Kristen Satya Wacana \\ ririntius@gmail.com \\ Bambang Ismanto \\ Magister Manajemen Pendidikan Universitas Kristen Satya Wacana \\ bambang.ismanto@staff.uksw.edu \\ Bambang Suteng Sulasmono \\ Magister Manajemen Pendidikan Universitas Kristen Satya Wacana \\ bambang.sulasmono@staff.uksw.edu
}

\begin{abstract}
The purpose of this study is to develop a school marketing strategy in increasing customer interest. This research is limited to the stage of product manufacturing. Data were collected using documentation study, observation, and in-depth interviews. Data is validated by source and techniques triangulation. Data analysis techniques using Miles and Huberman Model (interactive model): data reduction, presentation data, and conclusion/verification. The result of this research: 1) the implemented strategy is to use a promotional strategy by spreading brochures and/or presentations to predetermined schools and churches, word of mouth organizing month language events every year, and activities/program held/followed by school, 2) obstacles and lack of marketing strategy implemented by this school in increasing the interest of learners that time management is not right, committee less active, foundation not yet involved, dissemination of brochure less effective, marketing is less extensive, does not yet have a document of school marketing strategy, and has not been able to ensure and communicate that the services offered are relevant to the needs of the community, and 3) The resulting product is a school marketing strategy based on the Delta Model in the interest of learners: a) Best Product Strategy: conducting holistic education through various school activities/programs that are unique and relevant to customer needs, and apply multi payment system to simplify customer conduct financial transactions; $b$ ) Total Customer Solutions Strategy: maximize resources owned by the company and facilitate the human resources who participate in the competitions/activities to meet their needs, and give appreciation of the effort/achievement of human resources; and c) System Lock-In Strategy: enforcing contract system with certain experts/clients within a certain period of time to lock customer, implement career path system for teachers and school staff, and have special cooperation and instructions which applies to alumni, high school favorites, certain universities, and other educational institutions.
\end{abstract}

Keywords: Delta Model, School Marketing Strategy, Student Interest

\section{Article Info}


Kelola: Jurnal Manajemen Pendidikan, Vol. 5, No. 1, Januari-Juni 2018

\section{PENDAHULUAN}

Sekolah merupakan salah satu lembaga yang didirikan untuk mencapai tujuan pendidikan nasional. Guna mencapai tujuan tersebut, setiap sekolah menetapkan visi dan misi. Visi merupakan tujuan yang harus dicapai oleh sekolah dalam kurun waktu yang panjang (5-10 tahun) (Muhaimin, Suti'ah, \& Prabowo, 2015). Misi adalah cara bagaimana mencapai visi (Kautsar, 2015). Sekolah perlu menetapkan hal-hal yang harus dilakukan (misi) untuk mencapai visi. Salah satu hal yang dapat dilakukan untuk mencapai visi dan misi yaitu melibatkan berbagai pihak terkait dalam mengelola dan mengembangkan strategi yang tepat.

Salah satu strategi yang dapat digunakan oleh sekolah dalam mengenalkan visi dan misi yaitu strategi pemasaran. Strategi pemasaran dapat menjadi sebuah terobosan baru bagi sekolah untuk mencapai tujuan yang ditetapkan. Sekolah sebagai lembaga nonprofit sekaligus segmen kelembagaan yang penting, tujuannya bukanlah penciptaan kekayaan ekonomi melainkan usaha untuk melakukan aktivitas yang secara positif akan mempengaruhi masyarakat pada umumnya (Hax, 2010). Sekolah perlu memperhatikan hal-hal yang telah, sedang, dan belum dilakukan untuk meningkatkan layanan bagi pelanggan jasa pendidikan. Melalui strategi pemasaran yang tepat, sekolah dapat meningkatkan minat pelanggan (termasuk minat peserta didik). Sekolah yang diminati pelanggan dan memiliki SDM yang bermutu akan tetap eksis dan mampu meningkatkan kualitas pendidikan.

Strategi pemasaran merupakan suatu rencana kegiatan atau usaha menyampaikan barang atau jasa dari produsen kepada konsumen (termasuk pelanggan), dan usaha menciptakan pertukaran yang memuaskan melalui kegiatan pendistribusian, sekaligus sebagai upaya penyesuaian dengan kondisi lingkungan eksternal (Wijaya, 2012;
Fransiska, tt). Pada penelitian ini, sekolah sebagai produsen perlu memahami keadaan dan kebutuhan (calon) pelanggan sehingga dapat menyediakan jasa yang relevan dengan kebutuhan pelanggan. Selain kondisi eksternal, sekolah juga perlu mempertimbangkan kondisi lingkungan internalnya. Dengan kata lain, keberhasilan strategi pemasaran sekolah tergantung pada kondisi lingkungan dan upaya pemenuhan kebutuhan pihak terkait baik secara internal maupun eksternal.

Berdasarkan penelitian yang sudah ada, banyak sekolah telah mengembangkan, mengimplementasikan, dan/atau mengevaluasi berbagai strategi pemasaran sekolah. Salah satu hasil penelitian yaitu penelitian Sumarni (2011) menyatakan bahwa strategi pemasaran SMP Kristen Satya Wacana Salatiga berdasarkan analisis SWOT): 1) kekuatan yang dimiliki yaitu minat, motivasi belajar yang tinggi, kualifikasi pendidikan guru yang tinggi, rombongan belajar kecil, prosentase lulusan tinggi dan nilai rata-rata UAN tinggi; 2) kelemahannya yaitu kemampuan siswa beragam, supervisi kurang dan belum ada jaringan alumni; 3) peluangnya yaitu motivasi siswa melanjutkan ke jenjang pendidikan tinggi, peluang guru untuk melanjutkan pendidikan dan hasil evalusi dapat digunakan untuk melanjutkan ke jenjang pendidikan yang lebih tinggi; dan 4) ancamannya yaitu image sekolah mahal dan eksklusif, tingginya persaingan sekolah, dan orang tua melihat keberhasilan anak dari hasil, bukan proses. Strategi yang diimplementasikan oleh SMP Kristen Satya Wacana Salatiga berdasarkan analisis SWOT adalah strategi SO. Dengan strategi ini, SMP Kristen Satya Wacana Salatiga telah menggunakan kekuatannya untuk memanfaatkan peluang yang ada.

Pengembangan strategi pemasaran juga harus mempertimbangkan berbagai aspek termasuk peraturan atau kebijakan yang berlaku. Permendikbud Nomor 14 Tahun 2018: Pasal 3 Ayat (1) menyatakan bahwa 
Strategi Pemasaran Sekolah Dalam Peningkatan Minat Peserta Didik ... | Ririn T. E. Margareta, dkk.

pelaksanaan PPDB bagi sekolah yang diselenggarakan pemerintah daerah dimulai pada bulan Mei setiap tahun, Pasal 16 Ayat (1) menyatakan sekolah yang diselenggarakan pemerintah daerah wajib menerima calon peserta didik yang berdomisili pada radius zona terdekat dari sekolah paling sedikit $90 \%$ dari total keseluruhan peserta didik yang diterima, Pasal 16 Ayat (2) menyatakan domisili calon peserta didik berdasarkan alamat pada kartu keluarga yang diterbitkan paling lambat 6 bulan sebelum pelaksanaan PPDB, dan Pasal 16 Ayat (6a) menyatakan sekolah yang diselenggarakan pemerintah daerah dapat menerima calon peserta didik melalui jalur prestasi yang berdomisili diluar radius zona terdekat tetapi paling banyak 5\% dari total keseluruhan peserta didik yang diterima. Hal ini berarti, sekolah yang tidak diselenggarakan oleh pemerintah daerah memiliki potensi yang sangat besar untuk menerima calon peserta didik tanpa mempertimbangkan asal/domisili siswa.

Berdasarkan dokumen, sekolah swasta yang dijadikan subyek penelitian ini mengalami penurunan jumlah peserta didik baru khususnya empat tahun terakhir. Hal ini tampak dari hasil PPDB pada setiap tahun pelajaran. Beberapa tahun sebelum tahun pelajaran 2017/2018, sekolah menyediakan 3 rombel dan terisi 3 rombel meskipun jumlah peserta didik menurun. Pada tahun pelajaran 2017/2018 menyediakan 3 rombel tetapi hanya terisi 2 rombel. Hal ini menginformasikan bahwa jumlah peserta didik baru di sekolah tersebut menurun dan belum mencapai kuota yang disediakan. Sekolah perlu mengevaluasi dan menindaklanjuti hal ini dan memaksimalkan kesempatan untuk menentukan segmentasi pelanggan dan mengembangkan strategi pemasaran yang tepat.

Berdasarkan studi pendahuluan, sekolah ini memiliki beberapa permasalahan lainnya: 1) strategi pemasaran yang diimplementasikan belum mencapai tujuan, 2) belum memiliki dokumen strategi pemasaran secara tertulis; 3) kurang sumber dana untuk perbaikan sarana-prasarana dan promosi; 4) jumlah SDM terbatas dan tidak seimbang dengan beban tugas yang diberikan; 5) memiliki tim promosi tetapi sebagian besar dipercayakan kepada kepala sekolah, guru, dan staf; 6) keterbatasan biaya untuk membayar jasa dosen/pengajar siswa yang akan mengikuti lomba tertentu; 7) komite sekolah kurang berperan dalam pemasaran; dan 8) yayasan belum terlibat dan dilibatkan dalam pemasaran sekolah. Permasalahan ini harus segera diatasi untuk mempertahankan keberadaan sekolah, menyampaikan tujuan pendidikan kepada masyarakat, dan meningkatkan minat (calon) pelanggan pendidikan termasuk (calon) peserta didik.

Terkait dengan masalah yang dihadapi sekolah tersebut, salah satu upaya yang dapat dilakukan oleh pihak terkait yaitu mengembangkan strategi pemasaran sekolah. Strategi pemasaran sekolah yang tepat yaitu strategi yang berpusat pada pelanggan (termasuk peserta didik). Sekolah dapat menggunakan Delta Model yaitu kerangka strategi yang memposisikan pelanggan sebagai pusat manajemen (Hax dan Dean, 2001; Hax, 2003; 2010). Model ini memberikan tiga pilihan strategi yaitu best product, total customer solutions, dan system lock-in. Setiap pilihan memberikan posisi strategis untuk merancang setiap strategi. Ditinjau dari studi dokumen, Delta Model belum pernah digunakan dalam menentukan strategi pemasaran sekolah. Selain itu, sekolah ini merupakan sekolah swasta yang memiliki kebebasan untuk menerima calon peserta didik. Lebih dari itu, sekolah ini perlu mengembangkan strategi pemasaran untuk meningkatkan minat pelanggan sekolah. Minat pelanggan merupakan ketertarikan dan kemauan untuk terhubung dengan sesuatu yang berada di luar dirinya (Siagian, 2013; Octavany, Wardani, \& Prasetyo, 2018). Minat 
pelanggan sekolah dapat ditunjukkan dengan kemauan mereka mendaftarkan diri/anaknya sebagai calon peserta didik, merekomendasikan sekolah kepada kerabat/orang lain, melibatkan diri dalam kegiatan-kegiatan sekolah termasuk dalam pemasaran sekolah, dan/atau mengajukan diri sebagai donatur sekolah. Oleh karena itu, peneliti akan menggunakan Delta Model untuk membuat produk berupa strategi pemasaran sekolah berdasarkan Delta Model dalam peningkatan minat peserta didik.

\section{METODE PENELITIAN}

Penelitian ini merupakan penelitian kualitatif menggunakan metode penelitian dan pengembangan. Langkah-langkah penelitian dan pengembangan menggunakan model Sugiyono namun hanya sampai langkah ketujuh yaitu pembuatan produk. Tempat penelitian yaitu salah satu sekolah swasta Salatiga. Subyek penelitian ini terdiri dari kepala sekolah, wakil kepala sekolah, guru, karyawan, siswa, orang tua siswa, calon siswa dan orang tua calon siswa. Teknik pengumpulan data meliputi studi dokumentasi, observasi, dan wawancara mendalam. Analisis data menggunakan Model Miles and Huberman: (1) Pengumpulan data, (2) Reduksi Data, (3) Display Data, (4) Verifikasi/ Kesimpulan. Uji validitas data yang digunakan dalam penelitian ini menggunakan uji ahli dan praktisi serta teknik triangulasi sumber dan teknik.

\section{HASIL PENELITIAN DAN PEMBAHASAN}

\section{Hasil Penelitian}

\section{Strategi Pemasaran Sekolah dalam Peningkatan Minat Peserta Didik}

Berdasarkan hasil wawancara, tujuan strategi pemasaran yaitu mendapatkan siswa baru sesuai dengan kuota yang disediakan oleh sekolah dan memperkenalkan sekolah kepada publik/masyarakat. Target utama dari pemasaran sekolah yaitu SD seakses/seiman khususnya SD yang berada dalam naungan yayasan yang sama. Target lainnya yaitu beberapa SD Negeri dan gereja. Pada Implementasi strategi pemasaran sekolah ini yaitu promosi. Sekolah melakukan promosi melalui kegiatan sekolah, menyebar brosur, presentasi ke beberapa sekolah dan gereja, mengikut sertakan siswa dalam lomba-lomba, memberikan pelayanan yang baik pada siswa dan orang tua, cerita dari mulut ke mulut (word of mouth), mengadakan bakti sosial, dan kepala sekolah mencari siswa dengan cara mendatangi rumah teman-temannya.

Khusus untuk SD yang berada dalam satu yayasan, sekolah menggunakan strategi "jemput bola" yaitu dengan cara mendatangi sekolah tersebut. Promosi di gereja dilakukan dengan mengambil bagian dalam pelayanan yaitu menampilkan paduan suara dari siswa/i dan melakukan pendataan calon siswa di Sekolah Minggu. Promosi melalui kegiatan sekolah khususnya dilakukan pada kegiatan Bulan Bahasa. Promosi untuk SD Negeri menggunakan pendekatan secara personal.

Hasil wawancara ini didukung dengan adanya dokumen data siswa, guru, dan brosur promosi sekolah. Berdasarkan data, jumlah siswa pada tahun ajaran 2012/2013-2017/2018 cenderung turun dari tahun ke tahun dan khusus pada tahun pelajaran 2017/2018 yang juga mengalami penurunan jumlah rombel. Jumlah guru tahun ajaran 2017/2018 yaitu 18 guru. Brosur yang digunakan merupakan brosur yang belum diperbaharui untuk tahun ajaran 2017/2018. Hal ini tampak antara lain dari visi sekolah, foto pengajar dan staf sekolah, dan foto kegiatan sekolah yang terdapat pada brosur.

Berdasarkan hasil observasi, sekolah menyelenggarakan Kegiataan Bulan Bahasa dengan mengundang beberapa SD dan SMP dari Salatiga dan luar Salatiga. Selain menyelenggarakan lomba-lomba Bulan Bahasa, sekolah juga membuka pendaftaran 
Strategi Pemasaran Sekolah Dalam Peningkatan Minat Peserta Didik ... | Ririn T. E. Margareta, dkk.

peserta didik baru saat kegiatan ini berlangsung.

\section{Hambatan dan Kekurangan Strategi Pemasaran dalam Peningkatan Pelanggan}

Berdasarkan hasil wawancara menginformasikan bahwa pelaksanaan strategi pemasaran belum sesuai dengan yang diharapkan. Hal ini disebabkan: manajemen waktu belum ketat, belum ada diferensiasi, promosi tidak dilakukan sejak semester ganjil, penyebaran brosur kurang efektif, jangkauan pemasaran kurang jauh, tidak presentasi ke beberapa sekolah yang dikunjungi tahun lalu, sumber daya manusia terbatas, keterbatasan dana promosi, belum memiliki dokumen strategi pemasaran, tidak mengetahui jadwal SD sehingga timing/waktu pelaksanaan kurang tepat (SD sudah libur/sedang try out), komite kurang aktif, yayasan belum terlibat dalam strategi pemasaran sekolah, dan SDM belum mampu mengubah pandangan masyarakat tentang SMP Negeri "gratis".

Pada bagian ini tidak dilakukan triangulasi teknik karena data yang terkumpul hanya menggunakan teknik wawancara.

\section{Strategi Pemasaran Sekolah Berdasarkan Delta Model dalam Peningkatan Minat Peserta Didik}

Strategi pemasaran berdasarkan Delta Model yang terdiri dari 3 pilihan strategi yaitu Best Product, Total Customer Solutions, dan System Lock-In. Setiap pilihan strategi terdiri dari posisi strateginya masing-masing. Kerangka kerja strategis Delta Model juga menjadi pertimbangan pokok dalam pembuatan strategi pemasaran sekolah berdasarkan Delta Model.

\subsection{Best Product Strategy}

Berdasarkan hasil wawancara, sekolah memiliki koordinator pengelola administrasi kesiswaan, sarana prasarana, dan keuangan. Untuk pembayaran, orang tua melakukan transfer via bank. Sistem keuangan terpusat dan dianggap konvensional sehingga perlu dipertimbangkan oleh kedua belah pihak. Saat ini, sekolah belum melakukan diferensiasi tetapi memiliki rencana untuk melakukan beberapa kegiatan/program tertentu sebagai bentuk diferensiasi.

\subsection{Total Customer Solutions Strategy}

Hal ini menginformasikan bahwa sekolah menarik, memuaskan, mempertahankan, dan mengembangkan pelanggan dengan melakukan promosi sekolah dan juga melibatkan siswa untuk memberikan testimoni. Sekolah mempertahankan kualitas layanan, melibatkan orang tua dalam kegiatan sekolah, menerima masukkan orang tua, memiliki program/kegiatan sekolah yang diimplementasikan, memberi informasi sedini mungkin kepada orang tua dan siswa, menyebar angket ke orang tua, komite, dan siswa, dan memfasilitasi kenaikan jabatan dan keikutsertaan guru/staf dalam seminar.

Sekolah juga mengedukasi pelanggan melalui program, kegiatan, dan pertemuanpertemuan yang diselenggarakan oleh sekolah meskipun masih bersifat informatoris. Dari segi komunikasi, sarana komunikasi yang digunakan antara sekolah dengan orang tua yaitu surat, telepon, tatap muka, dan grup whatsapp. Selain sarana tersebut, komunikasi dengan guru dan staf juga melalui pertemuan harian dan rapat. Sekolah memiliki kerjasama antara lain dengan sekolah-sekolah yang berada dalam satu yayasan, universitas tertentu, Sido Muncul, dan Sosro.

Sekolah menjalin kerjasama dengan sekolah-sekolah yang berada dalam satu yayasan dalam menyelenggarakan kegiatan sekolah maupun promosi, dengan dosen suatu universitas dalam mempersiapkan siswa meng-ikuti lomba atau menjadi pembicara pada seminar yang diadakan oleh sekolah, dan dengan fakultas suatu universitas misalnya menerima mahasiswa praktikum. Selain itu, Pemerintah melalui dinas pendidikan juga berperan dalam memberikan anggaran untuk pengadaan komputer dan keperluan sarana dan prasarana lainnya. 


\subsection{System Lock-In Strategy}

Hasil wawancara menginformasikan bahwa sekolah belum memiliki sarana yang unik untuk menjangkau pelanggan. Salah satu alasan siswa bersekolah di sekolah ini yaitu orang tua atau kakek mereka adalah alumni. Sekolah sudah memiliki niat untuk membentuk jaringan alumni tetapi belum tercapai. Sekolah juga memiliki web tetapi belum dimaksimalkan.

Strategi pemasaran sekolah melalui promosi sudah melibatkan guru, staf, siswa, orang tua, dan komite. Melalui hubungan personal dapat tercipta word of mouth dari pelanggan kepada pelanggan lain/ calon pelanggan. Kontribusi intelektual dari pihak universitas berupa mahasiswa praktik dan dosen. Sekolah melibatkan dosen untuk mengajar/menjadi pembicara saat seminar orang tua dan/atau anak. Sekolah memfasilitasi siswa yang mengikuti OSN dengan pembelajaran yang dibimbing oleh dosen. Sekolah biasanya mengundang dosen sebagai pembicara dalam kegiatan sekolah atau sebagai pengajar OSN. Sekolah mengadakan seminar/kegiatan dan pembicara dari luar sekolah. Sekolah juga memiliki guru ekskul basket yang hanya melatih siswa/i sekolah tersebut. Beberapa tahun yang lalu, komite pernah melibatkan dosen untuk menjadi pengurus komite.

\section{Pembahasan}

\section{Strategi Pemasaran dalam Peningkatan Minat Peserta Didik}

Berdasarkan wawancara dan hasil penelitian, tujuan strategi pemasaran sekolah yaitu mendapatkan siswa baru sesuai dengan kuota yang disediakan. Hal ini sejalan dengan penelitian Abrori (2015) yaitu tujuan strategi pemasaran yaitu meningkatkan minat peserta didik. Tujuan ini sangat logis karena setiap sekolah pasti menginginkan kursi-kursi yang disediakan untuk siswa baru terisi penuh dengan jumlah pendaftar lebih banyak dari jumlah kursi yang tersedia bahkan meningkat dari tahun ke tahun. Selain mendapatkan siswa baru sesuai kuota, tujuan strategi pemasaran sekolah yaitu memperkenalkan diri kepada masyarakat luas. Hal ini senada dengan pendapat Wijaya (2016), tujuan strategi pemasaran sekolah untuk meyakinkan masyarakat dan pelanggan pendidikan akan keberadaan dan ketersediaan jasa yang relevan dengan kebutuhan mereka. Pernyataan lain yang mendukung yaitu pernyataan dari Asrori (2016) \& Putri (2016), tujuan pemasaran pendidikan yaitu mengetahui dan memahami kebutuhan pelanggan untuk memberikan pelayanan yang sesuai dengan kebutuhan pelanggan. Sekolah yang mampu menyediakan layanan jasa sesuai dengan kebutuhan pelanggan akan menjadi pilihan utama calon pelanggan dan lebih mudah mempertahankan pelanggan yang sudah ada. Namun pada kenyataannya, tujuan strategi pemasaran sekolah ini belum tercapai. Sekolah perlu memahami dan mempelajari cara-cara yang diperlukan untuk menarik minat masyarakat dalam pengambilan keputusan pembelian jasa pendidikan (Zulhelmi, 2017: 230). Hal ini juga berarti bahwa sekolah perlu menganalisis apa saja yang telah, sedang, dan akan dilakukan untuk menarik minat masyarakat termasuk minat pelanggan khususnya minat peserta didik sehingga mencapai tujuan strategi pemasaran.

Tujuan strategi pemasaran juga perlu dievaluasi baik dari segi kualitas maupun kuantitas. Tujuan pemasaran yang mengarah pada kuantitas dapat dilihat dari jumlah siswa baru yang diterima sedangkan yang mengarah pada kualitas misalnya, pemberian layanan/penyampaian jasa pendidikan kepada konsumen secara memuaskan (sesuai selera konsumen) (Alma, 2003: 46). Hal ini menunjukan bahwa setiap pemasar sekolah harus mampu memasarkan layanan jasa dengan cara yang menarik dan memuaskan pelanggan. Dalam hal ini, sekolah perlu mempersiapkan pemasar termasuk pelanggan, 
Strategi Pemasaran Sekolah Dalam Peningkatan Minat Peserta Didik ... | Ririn T. E. Margareta, dkk.

komplemen, dan pihak terkait lainnya untuk juga mampu menjadi pemasar sekolah. Salah satu cara yang dapat ditempuh yaitu mendatangkan ahli pemasaran pendidikan untuk mentransfer pengetahuan kepada pemasar sekolah. Hal ini sejalan dengan hasil penelitian Tyagita (2016), salah satu keberhasilan strategi pemasaran yaitu mengundang seorang ahli pemasaran untuk mengajar tim promosi melakukan pemasaran. Bila ahli pemasaran mengajar dan memotivasi setiap pihak terkait maka mereka akan mampu dan mau memasarkan sekolah. Pada akhirnya tujuan strategi pemasaran yang telah ditetapkan dapat tercapai. Setiap pemasar perlu mengetahui bahwa strategi pemasaran sekolah adalah setiap langkah yang diambil sekolah untuk berkomunikasi dengan masyarakat dan bertujuan untuk mencapai target atau sasaran yang sudah ditetapkan (Putri, 2016). Langkahlangkah strategi pemasaran sekolah perlu direncanakan, dilaksanakan, dikontrol, dan dievaluasi sedemikian rupa sehingga dapat diketahui ketercapaian tujuannya.

Sekolah juga perlu menentukan target strategi pemasaran untuk mencapai tujuan yang telah ditetapkan. Pemasar sekolah dan pihak terkait perlu menentukan target yaitu kelompok pelanggan yang akan dituju (targeting) (Indrajaya, 2008). Berbeda dengan sekolah-sekolah yang diselenggarakan oleh pemerintah, sekolah ini memiliki kebebasan untuk menentukan target pemasaran. Sekolah ini melakukan presentasi ke beberapa sekolah yang telah ditentukan. Hal ini juga dilakukan oleh SMA Islam Nurul Amanah yaitu mengunjungi target sekolah di beberapa kecamatan Asrori (2016). Sebagai sekolah swasta termasuk sekolah ini dituntut untuk lebih mandiri dalam mempertahankan eksistensi dan meningkatkan jasa yang ditawarkan kepada target pemasaran yang tepat.

Target utama yang ditentukan yaitu SD seakses khususnya SD dalam yayasan yang sama. Target lainnya yaitu SD Negeri, SD swasta lainnya, dan beberapa gereja. Penentuan target (targeting) merupakan salah satu strategi pemasaran sederhana selain segmenting dan positioning (Indrajaya, 2008). Beberapa hasil penelitian menunjukkan bahwa target pemasaran Madrasah Ibtidaiyah Nurul Islam Pongangan Gresik yaitu TK (Putri, 2016), target pemasaran SMA Batik 1 Surakarta yaitu SMP (Lestari, 2011), target pemasaran SMK N 1 Ngawen yaitu SMP (Nugroho, 2013), target pemasaran SMA Islam Nurul Amanah yaitu SMP dan MTs Nurul Amanah (Asrori, 2016), dan target pemasaran SMA Sedes Sapientiae Jambu yaitu SMP diberbagai daerah Jawa (Tyagita, 2016). Penentuan target pemasaran merupakan salah satu aspek yang menentukan keberhasilan tujuan pemasaran. Penentuan target pemasaran pada setiap tingkat pendidikan berbeda. Pada tingkat SD/sederajat, penentuan target pemasaran berdasarkan lokasi/ jarak tempuh. Sedangkan pada tingkat SMP /sederajat, penentuan target pemasaran tidak hanya berdasarkan lokasi/jarak tempuh tetapi lebih pada kebutuhan siswa dan pelanggan lainnya. Selain itu, sebagai sekolah swasta yang mendapatkan kebebasan dalam menentukan target pemasaran harus memaksimalkan kesempatan ini.

Sekolah ini telah menerapkan strategi pemasaran yaitu promosi diantaranya menyebar brosur dan/atau melakukan presentasi ke beberapa sekolah dan gereja yang telah ditentukan, mengadakan kegiatan sekolah khususnya Bulan Bahasa, memenangkan lomba-lomba yang diikuti oleh siswa, dan memberikan pelayanan yang baik untuk siswa dan orang tua. Hal ini sejalan dengan hasil penelitian Putri (2016), Madrasah Ibtidaiyah Nurul Islam Pongangan Gresik juga menjalankan strategi pemasaran melalui brosur dan kegiatan sekolah yang produktif. Senada juga dengan hasil penelitian Asrori (2016), SMA Islam Nurul Amanah juga 
menyebar brosur dan banner sebagai salah satu strategi pemasaran sekolah. Hasil penelitian lain yang mendukung yaitu strategi pemasaran yang paling efektif adalah promosi dengan presentasi dan program Jakumikat (Jalur Khusus Minat dan Bakat) ke alumni (Lestari, 2011 dan Nugroho, 2013). Hal ini menunjukan bahwa promosi dengan cara presentasi dan program Jakumikat telah diterapkan oleh sekolah lain. Dalam pengelolaan strategi pemasaran, sekolah ini dapat mengadakan program Jakumikat dan program lain yang memiliki keunikan untuk menjangkau pelanggan. Melalui program yang unik dapat mengunci pelanggan dan menghalangi lembaga lain memperoleh pelanggan (System Locik-In).

Strategi pemasaran sekolah ini juga melalui cerita dari mulut ke mulut (word of mouth) bahkan kepala sekolah ke rumah teman-teman gerejanya untuk mencari calon siswa. Sejalan dengan hal tersebut, hasil penelitian Khanifudin (2013) yaitu cerita dari mulut ke mulut (Word of Mouth/ WOM) yang telah diterapkan oleh SD Al Firdaus Surakarta dengan media WOM melalui tatap muka, telepon, dan website. Dengan WOM, (calon) pelanggan mendapatkan informasi secara verbal tentang jasa yang ditawarkan oleh sekolah. Selain tatap muka, telepon, dan website, media lain juga dapat dijadikan sarana WOM. Seiring berkembangnya teknologi dan informasi, sekolah dapat menggunakan berbagai media sebagai sarana WOM misalnya email, whatsapp, facebook, Instagram, skipe, dan sebagainya.

Strategi pemasaran yang digunakan untuk SD dalam satu yayasan yang sama yaitu strategi “jemput bola" dengan pendekatan melalui komite, mengadakan presentasi, dan try out. Senada dengan hasil penelitian Asrori (2016) yang menyatakan bahwa SMA Islam Nurul Amanah menggunakan strategi pemasaran dengan cara mengunjungi target sekolah di beberapa kecamatan. Strategi "jemput bola" yaitu mendatangi target pemasaran dan melakukan sosialisasi/ presentasi tentang jasa yang ditawarkan kepada pelanggan. Melalui strategi ini, pelanggan dapat bertanya dan mendapatkan jawaban secara langsung.

Promosi di gereja menggunakan pendekatan melalui kepala sekolah, mengirim brosur, persembahan pujian (paduan suara/vocal group siswa), dan mendata siswa Sekolah Minggu. Selain itu, kegiatan sekolah juga dijadikan sarana untuk promosi khususnya kegiatan rutin tahunan yaitu Bulan Bahasa. Pada kesempatan ini, sekolah mengundang beberapa SD-SMP yang ada di Salatiga dan luar Salatiga. Selain itu, sekolah memberikan potongan khusus bagi pendaftar sekaligus pemenang lomba Bulan Bahasa. Hal ini senada dengan hasil penelitian Putri (2016), salah satu strategi pemasaran Madrasah Ibtidaiyah Nurul Islam Pongangan Gresik melalui kegiatan produktif. Kegiatan-kegiatan sekolah tidak hanya terbatas sebagai strategi pemasaran tetapi juga dapat memperkaya/ meningkatkan kompetensi dan kapabilitas sumber daya yang ada. Seiring dengan itu, hasil penelitian Haryanto \& Roza (2012) menyatakan bahwa melalui strategi pemasaran internal dengan mengembangkan kemampuan SDM internal dalam mencapai kompetensi yang memadai. Melalui strategi process, sekolah mengoptimalkan citra positif yang memiliki value added dalam integritas, karakter, disiplin, dan tertib menjaring pelanggan yang loyal (Nugroho, 2013). Dengan kompetensi, dan kapabilitas sumber daya yang memadai bahkan melebihi ekspektasi, sekolah dapat mengelola termasuk mengimplementasi strategi yang tepat untuk mencapai tujuan yang ditetapkan.

\section{Hambatan dan Kekurangan Strategi Pemasaran dalam Peningkatan Pelanggan}

Setiap strategi perlu dievaluasi guna mengetahui hal-hal yang perlu diperbaiki, dipertahankan, ataupun ditingkatkan. 
Hambatan dan kekurangan yang ada perlu ditinjau ulang sebagai bahan untuk merevisi strategi di waktu yang akan datang. Hambatan dan kekurangan strategi dapat menyebabkan tujuan yang ditetapkan tidak tercapai. Demikian pula dengan strategi pemasaran yang diimplementasikan oleh sekolah ini belum mencapai tujuan yang diharapkan. Hal ini dikarenakan ada beberapa hambatan dan kekurangan: 1) jumlah SDM yang terlibat terbatas dan memiliki tugas pokok dan fungsi yang lain, 2) tidak ada diferensiasi, 3) manajemen waktu yang tidak tepat (kegiatan pemasaran terlambat dimulai, beberapa sekolah yang dikunjungi sedang sibuk), 4) penyebaran brosur tidak efektif, 5) jangkauan pemasaran kurang jauh, 6) tidak mengunjungi sekolah yang dikunjungi tahun lalu, 7) promosi di gereja terbatas pada beberapa gereja yang ada di Salatiga, 8) keterbatasan dana promosi, 9) yayasan belum terlibat/dilibatkan dalam kegiatan pemasaran, 10) belum memiliki dokumen strategi pemasaran sekolah, dan 11) belum mampu memastikan dan mengkomunikasikan bahwa sekolah hadir untuk memenuhi kebutuhan pelanggan. Senada dengan hasil penelitian Asrori (2016), hambatan strategi pemasaran yang serupa juga dialami oleh SMA Islam Nurul Amanah yaitu hambatan yang berasal dari faktor internal (belum maksimal dalam melakukan sosialisasi dan persepsi masyarakat terkait hafalan AlQur'an yang menjadi beban bagi anak) dan eksternal sekolah (persaingan antar lembaga pendidikan). Hambatan-hambatan yang ada dapat diatasi dengan melakukan berbagai upaya perbaikan misalnya menjalin hubungan dan melibatkan berbagai pihak terkait dalam mengembangkan strategi pemasaran sekolah.

Pelanggan, komplemen, dan pihak terkait lainnya perlu diedukasi sehingga implementasi strategi dapat berjalan sesuai dengan perencanaan dan mencapai tujuan yang diharapkan. Kepala sekolah sebagai pemimpin sekaligus manager dapat bekerjasama dengan wakil kepala sekolah dan pihak-pihak terkait untuk memasarkan sekolah. Hal ini telah dilakukan oleh kepala dan wakil kepala Madrasah Ibtidaiyah Nurul Islam Pongangan Gresik yang berupaya menggandeng tokoh masyarakat dalam memasarkan sekolah (Putri, 2016). Selain itu, sekolah dapat menganalisis permasalahan pemasaran melalui musyawarah bersama dalam pemecahan masalah dan selalu menjalin hubungan yang baik dengan pihakpihak yang mendukung tercapainya tujuan sekolah (Asrori, 2016). Terkait dengan perkembangan teknologi, kegiatan pemasaran yang dilakukan perlu mencocokkan sumber informasi dengan kebutuhan siswa (Moogan, 2011). Melalui pemanfaatan teknologi yang maksimal, dan komunikasi yang transparan dan terkoordinasi antar pihak dalam kegiatan pemasaran sekolah, tujuan dapat dicapai dengan lebih efisien dan efektif.

\section{Strategi Pemasaran Sekolah Berdasarkan Delta Model dalam Peningkatan Minat Peserta Didik}

Berbagai strategi pemasaran telah diterapkan oleh lembaga profit maupun nonprofit. Saat ini banyak sekolah (lembaga nonprofit) yang menerapkan strategi pemasaran. Sebagai salah satu strategi penting, strategi pemasaran perlu dikelola sesuai dengan kebutuhan pelanggan, bukan hanya melakukan diferensiasi. Hal ini senada dengan Wijaya (2016), strategi pemasaran diperlukan karena sekolah perlu meyakinkan pelanggan bahwa sekolah yang dikelola masih eksis dan jasa yang ditawarkan relevan dengan kebutuhan mereka. Namun, alih-alih ingin tampil berbeda dengan sekolah lain, beberapa sekolah tergoda untuk melihat strategi pemasaran sekolah lain dan meniru kemudian melakukan modifikasi sesuai versi sekolah tanpa mempertimbangkan kebutuhan pelanggan. Hasil dari tindakan ini tidak dapat menjamin terpenuhinya kebutuhan pelanggan.

Dalam pengelolaan dan pengembangan strategi pemasaran, sekolah dapat mengguna- 
kan berbagai alat analisis atau berdasarkan model tertentu. Salah satu alat analisis yang sering digunakan yaitu SWOT. Beberapa penelitian yang menggunakan analisis SWOT yaitu strategi pemasaran SMP Kristen Satya Wacana Salatiga (Sumarni, 2011), SMA Batik 1 Surakarta (Lestari, 2011), dan PT Duta Pratama Jaya (Triastuti, 2003). Melalui analisis dan matriks SWOT diperoleh empat tipe strategi yang dapat diterapkan yaitu strategi SO, strategi ST, strategi WO, dan strategi WT.

Dalam pengembangan strategi pemasaran juga dapat didasarkan pada bauran pemasaran, Porter, RBV, dan Delta Model. Pada penelitian ini, strategi pemasaran yang dibuat didasarkan pada Delta Model yang dikemukakan pertama kali oleh oleh Hax dan Wilde (2001) dan dikembangkan oleh Hax (2003, 2010). Kerangka strategis Delta Model yang dikembangkan pada penelitian ini meliputi empat langkah yaitu 1) segmentasi dan proposisi nilai pelanggan, 2) kompetensi, kapabilitas, dan sumber daya, 3) misi, dan 4) agenda strategis. Kerangka strategis Delta Model ditentukan berdasarkan analisis hasil penelitian. Pada bagian ini, juga akan dibahas tiga pilihan strategi pada Delta Model untuk meningkatkan minat peserta didik sekolah ini.

\subsection{Best Product Strategy}

Melalui Best Product Strategy, sekolah dapat mengembangkan posisi strategi diferensiasi dan efisiensi administrasi (Hax, 2010). Dengan kata lain, diferensiasi yang diciptakan atau dikembangkan tetap memperhitungkan efektifitas dan efisiensi dari berbagai sudut pandang. Sekolah dapat melakukan diferensiasi dengan menyelenggarakan berbagai kegiatan/program sekolah yang unik berlandaskan pendidikan holistik misalnya mengelola kegiatan belajar mengajar di dalam dan di luar kelas sesuai dengan kebutuhan pelanggan. Hal ini ini sejalan dengan hasil penelitian Putri (2016), Madrasah Ibtidaiyah Nurul Islam Pongangan
Gresik melakukan kegiatan yang produktif, menarik, dan melibatkan masyarakat, serta menggunakan media sosial sebagai media pemasaran. Hasil penelitian Triastuti juga senada yaitu PT Duta Pratama memiliki strategi diferensiasi berupa keunikan produk dengan menambah/mengkombinasi bahan alami untuk memenangkan pasar dalam maupun luar negeri. Sekolah juga dapat memfasilitasi SDM untuk mengembangkan minat dan bakatnya, melibatkan pelanggan dalam mengembangkan strategi pemasaran, dan mengadakan kegiatan indoor ataupun outdoor.

Efisiensi administrasi dapat dilakukan dengan menerapkan multi payment dan membuat RKAS sesuai dengan kebutuhan pelanggan melalui kegiatan/program sekolah yang unik. Tujuan dari efisiensi administrasi sekolah tidak hanya mencapai efisiensi tetapi juga efektifitas administrasi dan kegiatan/ program yang akan dilaksanakan. Sekolah dapat menyebar angket untuk mengetahui kebutuhan pelanggan. Dalam menarik pelanggan, sekolah juga dapat memberi akses kepada masyarakat untuk menggunakan sarana dan prasarana sekolah melalui prosedur yang ditentukan oleh pihak sekolah. Selain menarik, sekolah dapat mempertahankan, dan mempertahankan pelanggan melalui keterlibatan alumni dalam kegiatan/program sekolah yang unik.

\subsection{Total Customer Solutions Strategy}

Dalam Delta Model, sekolah juga dapat mengembangkan Total Customer Solutions Strategy yang sangat mendukung dalam penciptaan ikatan yang kuat antar pelanggan dan antara pelanggan/komplemen/pihak terkait dengan penyedia jasa. Dengan ikatan yang kuat, penyedia jasa dapat memahami kebutuh-an pelanggan dengan baik dan memberikan layanan jasa yang relevan. Sekolah dapat memenuhi seluruh kebutuhan pelanggan yang relevan dan sesuai dengan kompetensi yang dimiliki oleh sekolah. 
Strategi Pemasaran Sekolah Dalam Peningkatan Minat Peserta Didik ... | Ririn T. E. Margareta, dkk.

Sekolah dapat memaksimalkan sumber daya yang dimiliki untuk mengelola dan mengembangkan website sekolah sebagai sarana untuk berbagi informasi tentang sekolah dan kegiatan/ program yang diselenggarakan/diikuti. Hal ini senada dengan hasil penelitian Khanifudin (2013), salah satu media word of mouth (WOM) yaitu pengembangan strategi pemasaran sekolah dapat dilakukan dengan mengintensifkan website. Hasil penelitian Tang, Yasa, \& Forrester (2004) juga senada yaitu aplikasi berbasis web dan internet memfasilitasi cara baru untuk mengirim produk dan layanan kepada pelanggan secara efektif dan efisien. Selain website, sekolah juga dapat menyediakan sarana komunikasi lainnya yang relevan dengan mengelola dan menyediakan prosedur/alur komunikasi antar pihak terkait.

\section{Melalui Total Customer Solutions}

Strategy, sumber daya yang dimiliki juga perlu difasilitasi dalam memenuhi kebutuhannya baik melalui pelatihan ataupun kegiatan produktif lainnya. Sekolah dapat memfasilitasi, mempersiapkan, mengikutsertakan, dan mengapresiasi usaha/pencapaian SDM yang mengikuti lomba/kegiatan tertentu. Sebagai contoh, guru dan staf difasilitasi dalam proses kenaikan jabatan, siswa difasilitasi dalam mengembangkan minat dan bakat melalui lomba ataupun ekstrakurikuler, dan orang tua difasilitasi dalam menyelenggarakan kegiatan orang tua (dan siswa). Hal ini sejalan dengan hasil penelitian Haryanto dan Rozza (2012), strategi internal yang dilakukan yaitu mengembangkan

kemampuan

petugas/pegawai Humas dalam mencapai kompetensi yang memadai.

\subsection{System Lock-In Strategy}

Pengembangan System Lock-In Strategy membutuhkan para pemikir yang "óut of the box", memikirkan strategi yang sulit bahkan tidak dapat ditiru oleh lembaga lain. Selain itu, dengan System Lock-In Strategy, tidak ada lembaga lain yang dapat mengakses pelanggan. Sekolah dapat mengunci pelanggan dengan sistem kontrak dengan ahli/lembaga tertentu. Sebagai contoh, sekolah dapat mengunci SD seyayasan melalui perjanjian/kontrak. Dalam hal ini dibutuhkan SDM yang kompeten untuk memfasilitasi dan mewujudkan system lock-in. Sekolah juga dapat menerapkan sistem jenjang karir bagi guru atau staf sekolah. Selain itu, melalui kerjasama dengan alumni, sekolah dapat membuat suatu prosedur khusus yang hanya berlaku untuk alumni. Demikian pula dengan lembaga lain yang relevan misalnya SMA/K favorit dan Universitas tertentu. Hal ini sejalan dengan hasil penelitian Tyagita (2016), salah satu kunci sukses pemasaran yaitu kegiatan yang menjalin hubungan baik dengan berbagai daerah, alumni, orang tua, panitia, dan penduduk setempat. Salah satu hasil penelitian Sitompul dan Nahartyo (2006) juga senada yaitu mewujudkan peluang kerjasama dengan komplementor. Hal ini dapat diartikan bahwa penting bagi sekolah untuk menjalin hubungan baik dengan siapa saja untuk meningkatkan minat pelanggan termasuk minat peserta didik.

\section{SIMPULAN DAN SARAN \\ Simpulan}

Berdasarkan hasil penelitian dan pembahasan diperoleh kesimpulan sebagai berikut:

1. Implementasi strategi pemasaran sekolah dalam peningkatan minat peserta didik yaitu menggunakan strategi promosi dengan menyebar brosur dan/atau presentasi ke sekolah dan gereja yang telah ditentukan, cerita dari mulut ke mulut (word of mouth) menyelenggarakan kegiatan lomba Bulan Bahasa setiap tahun, dan kegiatan/program yang diselenggarakan/diikuti oleh sekolah.

2. Hambatan dan kekurangan strategi pemasaran sekolah yang diimplementasikan oleh sekolah ini dalam peningkatan minat peserta didik yaitu manajemen waktu 
belum tepat, komite kurang terlibat aktif, yayasan belum terlibat, penyebaran brosur kurang efektif, jangkauan pemasaran kurang luas, belum memiliki dokumen strategi pemasaran sekolah, dan belum mampu memastikan dan mengkomunikasikan bahwa jasa yang ditawarkan relevan dengan kebutuhan masyarakat.

3. Produk yang dihasilkan yaitu strategi pemasaran sekolah berdasarkan Delta Model dalam peningkatan minat peserta didik: 1) Best Product Strategy: menyelenggarakan pendidikan holistik melalui berbagai kegiatan/program sekolah yang unik dan relevan dengan kebutuhan pelanggan, serta memberlakukan multi payment system untuk mempermudah pelanggan dalam melakukan transaksi keuangan, 2) Total Customer Solutions Strategy: memaksimalkan sumber daya yang dimiliki dengan mengembangkan website sekolah dan sarana komunikasi lain yang relevan serta menyediakan prosedur/alur komunikasi antar pihak terkait, memfasilitasi SDM yang mengikuti lomba/kegiatan tertentu untuk memenuhi kebutuhan mereka, dan memberikan apresiasi atas usaha/pencapaian SDM, dan 3) System Lock-In Strategy: memberlakukan sistem kontrak dengan ahli/ lembaga tertentu dalam jangka waktu tertentu untuk mengunci pelanggan, menerapkan sistem jenjang karir bagi guru dan staf sekolah, dan memiliki kerjasama serta prosedur khusus yang berlaku untuk alumni, SMA/K favorit, Universitas tertentu, dan lembaga pendidikan lainnya.

\section{Saran}

Saran penelitian ini ditujukan kepada:

1. Kepala sekolah dan pihak terkait, menjadi penelitian ini sebagai acuan dalam melaksanakan dan mengembangkan strategi pemasaran di waktu mendatang.
2. Direktur sekolah, menjadikan penelitian ini sebagai salah satu bahan pertimbangan/ masukan untuk mengevaluasi dan mengembangkan strategi pemasaran sekolah.

3. Bagi penelitian berikutnya, menjadikan penelitian ini sebagai salah satu referensi khususnya di bidang manajemen pemasaran jasa pendidikan.

\section{DAFTAR PUSTAKA}

Asrori, B. 2016. Strategi Pemasaran Sekolah dalam Upaya Meningkatkan Partisipasi Masyarakat di SMA Islam Nurul Amanah Kecamatan Tragah Kabupaten Bangkalan. Inspirasi Manajemen Pendidikan, 2(2).

Abrori, M. 2015. Strategi Pemasaran Lembaga Pendidikan untuk Meningkatkan Jumlah Peserta Didik di PG/TK Samarinda. SYAMIL, 3(2).

Alma, B. 2003. Pemasaran Stratejik Jasa Pendidikan. Bandung: Alfabeta.

Fransiska, R. Kebijakan Strategi Pemasaran Sekolah Tinggi Ilmu Ekonomi (STIE) Palangka Raya. Jurnal Sains Manajemen, 1 (1), 69-85.

Haryanto, R., \& Rozza, S. 2012. Pengembangan Strategi Pemasaran dan Manajemen Hubungan Masyarakat Dalam Meningkatkan Peminat Layanan Pendidikan. Jurnal Ekonomi dan Bisnis, 11(1), 27-34.

Hax, A. C. 2010. The Delta Model: Reinventing Your Business Strategy. Springer Science \& Business Media.

Hax, A. C., \& Wilde, D. L. 2003. The Delta Model-A New Framework of Strategy. Journal of Strategic Management Education, 1(1), 1-21.

Hax, A., \& Wilde II, D. 2001. The Delta Model-Discovering New Sources of Profitability in A Networked 
Strategi Pemasaran Sekolah Dalam Peningkatan Minat Peserta Didik ... | Ririn T. E. Margareta, dkk.

Economy. European Management Journal, 19(4), 379-391.

Indrajaya, R. 2008. Jangan Takut Memulai Bisnis. Jakarta: MeBook.

Kautsar, E. M. 2015. Be A Passionpreneur! 11 Langkah Menjadikan Hobi sebagai Profesi yang Menyukseskan dan Membahagiakan. Jakarta: Gramedia Pustaka Utama.

Khanifudin, K. 2013. Pengembangan Strategi Pemasaran Sekolah Berbasis Word of Mouth Di SD Al Firdaus Surakarta (Doctoral dissertation, Universitas Muhammadiyah Surakarta).

Lestari, S. 2011. Strategi Pemasaran Sekolah di SMA Batik 1 Surakarta (Doctoral dissertation, Universitas Muhammadiyah Surakarta).

Moogan, Y. J. 2011. Can A Higher Education Institution's Marketing Strategy Improve the Student-Institution Match? International journal of educational management, 25(6), 570589.7

Muhaimin, Suti'ah, \& Prabowo. 2015. Manajemen Pendidikan: Aplikasinya dalam Penyusunan Rencana Pengembangan Sekolah/ Madrasah. Jakarta: Prenadamedia Group.

Nugroho, S. A. 2013. Strategi Pemasaran Sekolah Berbasis Bauran Pemasaran: $\begin{array}{llll}S M K & N & 1 & \text { Ngawen, }\end{array}$ Gunungkidul (Doctoral dissertation, Universitas Muhammadiyah Surakarta).

Octavany, Y., Wardani, N. S., \& Prasetyo, T. (2018). Efektivitas Pendekatan Inkuiri dan Model Jigsaw (Pi-Mj) terhadap Minat Belajar Siswa Kelas 4 SD. PENDEKAR| FKIP UMMat, 1(1), 226-231.
Permendikbud. 2018. Peraturan Menteri Pendidikan dan Kebudayaan Republik Indonesia Nomor 14 Tahun 2018 tentang Penerimaan Peserta Didik Baru pada Taman Kanak-kanak, Sekolah Dasar, Sekolah Menengah Pertama, Sekolah Menengah Atas, Sekolah Menengah Kejuruan, atau Bentuk Lain yang Sederajat. Jakarta: Kepala Biro Hukum dan Organisasi Kementerian Pendidikan dan Kebudayaan.

Putri, M. I. 2016. Strategi Pemasaran Sekolah (Studi Kasus di Madrasah Ibtidaiyah Nurul Islam Pongangan Gresik). Inspirasi Manajemen Pendidikan, 1(1).

Siagian, R. E. F. 2013. Pengaruh Minat dan Kebiasaan Belajar Siswa Terhadap Prestasi Belajar Matematika. Jurnal Formatif, 2(2), 122-131.

Sitompul, Y. C., \& Nahartyo, E. 2006. Strategi Bank BRI Dalam Penyaluran Kredit Mikro Melalui Pendekatan Delta Model (Doctoral dissertation, Universitas Gadjah Mada).

Sugiyono. 2015. Metode Penelitian dan Pengembangan (Research and Development/ $R \& D)$. Bandung: Alfabeta.

Tang, N. K., Yasa, P. R., \& Forrester, P. L. 2004. An Application of the Delta Model and BPR in Transforming Electronic Business-The Case of A Food Ingredients Company in UK. Information Systems Journal, 14(2), 111-130.

Tyagita, B. P. A. 2016. Strategi Pemasaran Sekolah Menengah Atas Swasta Berasrama di Kabupaten Semarang 1. Kelola: Jurnal Manajemen Pendidikan, 3(1), 67-79. 
Kelola: Jurnal Manajemen Pendidikan, Vol. 5, No. 1, Januari-Juni 2018

Triastuti, Y. D. 2003. Strategi Diferensiasi Produk Sebagai Strategi Memenangkan Persaingan di Pasar Luar Negeri (Doctoral dissertation, Universitas Gadjah Mada).

Wijaya, D. 2012. Pemasaran Jasa Pendidikan. Jakarta: Salemba Empat.

Wijaya, D. 2016. Pemasaran Jasa Pendidikan. Jakarta: Bumi Aksara.

Zulhelmi, Z., \& Ayu, A. F. 2017. Analisis Faktor-Faktor yang Mempengaruhi Keputusan Pembelian Jasa di SMP Kristen Kalam Kudus Pekanbaru. PROCURATIO (Jurnal Ilmiah Manajemen), 3(3), 228-240. 